\title{
Influence of Student Councils Participation in Decision Making on Management of Public Boys' and Girls' Boarding Secondary Schools, Nyeri County, Kenya
}

\author{
Eustace Murage Muthui \\ George M. Muthaa \\ Barchok K. Hillary \\ Department of Education \\ Chuka University \\ Meru- Kenya \\ David K. Wamukuru \\ Department of Curriculum \\ Instruction and Educational Management \\ Egerton University, Kenya
}

\begin{abstract}
The aim of this study was to determine the influence of the participation of students' councils in enhancing the management in boys' and girls' public boarding secondary schools. The study adopted the descriptive survey and correlation research designs. The study was conducted in 12 boys' and 12 girls' public boarding secondary schools in Nyeri County that were identified using purposive sampling technique. A sample of 384 respondents was used. Data was collected using questionnaires and interview schedules. Data was analyzed using both descriptive and inferential statistics. The study established that participation of student councils influenced the management of public boarding secondary schools by $49 \%$ in decision making. The study recommended that the student council should participates in meeting where decisions for management of the school are made and also hold open forum where students' issues are discussed and feedback given to the school administration.
\end{abstract}

Keyword: School management; Students Council; Decision making; Secondary school

\subsection{Introduction}

\subsection{Background of the Study}

The management of secondary school is the responsibility of a wide range of stakeholders (Black \& Walsh, 2009). In Kenya education stakeholders include the Ministry of Education (MOE), the Board of Management (BOM), the school administration, Parent Association (PA), teaching and support staff, the students, student leaders among others (Republic of Kenya, 1999). The responsibilities of the school stakeholders are to ensure that the curriculum, finances, human resources and the physical facilities are well managed and maintained (Republic of Kenya, 2015). Thus, it is the responsibility of the school management to ensure that internally, the necessary planning, implementation, monitoring and evaluation process are adhered to so that the ultimate goal of providing universal quality education for the children is realized (Wango, 2009). The school management also makes maximum benefit from the feedback that is received from the monitoring and evaluation process for the purpose of filling gaps in the process to ascertain found for continuous improvement of the institution (Hoy \&Miskel, 2013). In a school management situation the position of student leaders as critical stakeholders in enhancing effective management cannot be underestimated.

The recognition of student leaders as critical stake holders is grounded on the foundation of specific engagement, assignment and delegation of duties by the school administration geared towards realizing effective school management (Wango, 2009). The specific responsibilities of the student leaders' are to coordinate students activities, participate in decisions making on behalf of the other students, resolving conflicts that arise among students with their teachers (MOE, 2010). They also include making the necessary communication to the students and the school administration in time raises the self-esteem of the students and inspires the future leadership of the society (Kamuri, 2014). 
It is the responsibility of the school management to identify and exploit the potential of the student leadership as invaluable instrument of realizing effective management of educational institutions (Stokes \& Turnbull, 2008). Once in place, the student leadership in secondary school management would engage in planning, organizing, directing, coordination and controlling students to willingly and enthusiastically enhance completion of scheduled program which implies management effectiveness for the benefit of the whole school (Gatabu, 2011). Thus, the student leaders remain one of the most influential stakeholder the school administration could engage to positively influence the rest of students enhance school management.

Following the student unrests in Kenya in 2008 the Ministry of Education (MOE), in collaboration with United Nations Children Education Fund (UNICEF) and Kenya Secondary Schools' Heads Association (KSSHA) mooted the Student Council (SC) concept. These would be an autonomous team of Student Council Leaders (SCLs) who would be elected democratically to represent the students (KESSHA/UNICEF, 2010). To enhance effective management of secondary schools the MOE in 2009 directed that secondary schools must transit from prefect bodies to student councils structure of student leadership within two years (MOE, 2010).

The student council policy was embraced by secondary schools management because it was expected to address issues that made students and teachers unhappy about prefects (Indimuli, 2012). Therefore, the student councils were implemented with enthusiasm that by the beginning of 2012, 77\% of schools had transited from the prefects to student councils leadership (Tirop, 2012). The establishment of student councils created democratic space among the students that was credited for the relative peace that was marked by decline in student unrest from a high prevalence of $7.4 \%$ in 2008 to $0.4 \%$ in 2011 in secondary schools in Kenya (Tirop, 2012). However, in year 2013, cases of student unrests rose to $0.49 \%$ of the number of secondary schools in Kenya. The only difference with student unrests in 2014 compared to those in 2008 were that they were accompanied with arson attacks (Republic of Kenya, 2014). In 2015 the situation was worse as 51 boys and 12 girls' public boarding secondary schools which constituted about 1\% of schools in Kenya were affected by student unrests (Masese, 2015). In 2016 the situation of student unrests had deteriorated from that of 2015. In total, 126 secondary schools which was rated $1.9 \%$ of all secondary schools in Kenya were affected (MOE, 2016). According to Ouma and Muide (2016) nationally, student unrests had affected 98 boys and 28 girls' secondary school resulting to suspension of studies for about 6000 students in the affected schools. This show more cases of student unrest among boys schools compared to the girls' schools.

The student unrests continued to be a matter of concern to education stakeholders despite the fact that there were elected student councils in those schools whose responsibility included prevention of student unrests to enhance management of secondary schools as per the expectations of the MOE when the student councils were introduced (Ndungu \& Kwasira, 2015). Student unrests often caught the school administration unaware despite fact that student council were expected to have known and presented the student grievances and made decisions a way forward in good time (Abuya \& Muhia, 2016). That raised doubts on whether the student councils were capable of influencing effective school management and prevents cases of student unrest. This study filled this gap by investigating the influence of student councils participation in decision making on management of public boys' and girls' boarding secondary schools.

In 2016, student unrests were recorded in five public boarding secondary schools in Nyeri County as at $30^{\text {th }}$ July where three were in boys and two were in girls' public boarding secondary schools (Ouma\&Muide, 2016). It is inquisitive whether the prevalence of fewer student unrests in girls' public boarding secondary school compared to the boys' schools is as a result of well-established and effective student councils in girls than in the boys' schools. This study sought to fill the literature gap by conducting a comparative study on the participation of student councils in public boys and girls public boarding secondary schools. The study focused on the participation of the student councils in decision making to influence effective management of public boys and girls boarding secondary schools in Nyeri County of Kenya.

\subsection{Literature Review}

\subsection{Student Leadershipin School Management}

According to Leithwood, et al,2004), student leadership is the exercise of power by a few students over the other students by setting up targets, giving direction, establishing interpersonal influence and motivation geared towards accomplishment of planned goals for the benefit of the whole school. 
The student leadership in secondary school management is involved in planning, organizing, directing and controlling student activities to conform to the school routine (Keogh \& Whyte, 2005). According to Huddleston (2007) student leadership provides a unique opportunity for students to acquire and practice management skills in welfare, boarding, accommodation, sports, health, environment and academics depending on the establishment of their school. School management borrows heavily from Likert's Management Systems that were developed after 30 years of extensive research on how good leadership would improve efficiency in an organization. Likert's research covered various firms and organizations, including schools and universities, and involving head teacher, teachers and students. The Likert's findings revealed that leaders use a combination of authoritative, benevolent, consultative and participative styles of management to achieve their institutional goals.

In school management according to Modaff, et al. (2008) there are consultative student leader has substantial but not complete confidence with his/her ideas. As a result the general decisions are made by the student leader and then sought the opinions of the students, and makes the finally decision. The student develops positive attitudes toward the school management and the student leaders when they are consulted. If the students feel that enough consultation has not taken place, they may publicly resist orders from the student leaders and the school administration and that becomes conflict which requires quick intervention in terms of decisions for normalcy to be restored in the institution. Communication flows from top to the bottom of the hierarchy. The student leader consults through relevant channels, with students on matters they would like to bring to the attention of the school administration. The school management usually delegates tasks to control students at lower levels which is done in terms of supervision and perceived as a way of maintaining the set standard.

Student councils in school management were expected to promote peace through participation in decisions making. Therefore the re-emergence of devastating student unrests in public boarding secondary schools in 2015 and 2016 show that there was a gap in implementation of the policy on participation of student council in school management. This study therefore, investigated the influence of student councils participation in decision making to influence effective management of public boarding secondary schools in Nyeri County.

\subsection{Participation of Student Councils in Decision Making}

Student leaders are involved in decision making is an intellectual stimulating process of selecting the best option that can maximize on the achievement of goals and objectives of their school(Lynn D. \&Yamashita H., 2007). The participation of students in decision making processes in learning institutions has been a subject of debated due to conflicting viewpoints propagated by different stakeholders opinion from different parts of the world (Magadla, 2007). There are three points of view that guide student involvement in decision making processes in secondary schools. The first viewpoint provides that teachers make decision on behalf of the students and present to them as policy directions while they take a passive role. That implies that the student leaders are considered by the school administration as immature (Sithole, 1998). The second point of view suggests that students are involved in decision making processes in their school but are excluded from participating in sensitive decision making processes such as those related to examinations, academic performance and appointment of teachers (Huddleston, 2007). The third point of view suggests that the principals and other stakeholders allow students to participate in decision making processes with regard to definite rules, rewards, curriculum, learning, development and planning of their school (Magadla, 2007).

In Kenya the promulgation of the new constitution complemented earlier reforms in education that had recommended transfer of some decision making authority to the stakeholders at the school level to ease the challenges of management and governance (Republic of Kenya, 2010). Among the targeted stakeholder were the students who are represented in the management by the student council members (UNICEF 2011). According to MOE (2010) the student councils in secondary school in Kenya, participate in the school decision making process to enhance institutional management by meeting regularly to discuss current issues affecting the students and presenting their recommendations to the school management. In their recommendations the student council should share and suggest alternative solutions to challenges facing school management.

Besides, the student council should seek a consensus with the school management on the implementation of solution to the problem that had been proposed. The decisions that are made by the student leaders with the school management should also be effectively communicated to the rest of the students to avoid suspicion and mistrust (Ruto-Korir, 2003). The student councils and the school management are responsible of implementing the decision that has been made and also giving feedback to the students and the school management. 
The influence of student council participation in decision making process is tested in enhancing the achievement of school goals which include realization of improved results in academic performance and peace in the school.

According to Tikoko and Kiprop (2011) participation student council in the decision making process in secondary schools is a sign of recognition of students as significant stakeholders in the management of the institution. As a result the chairpersons of student councils should be invited to the school management meetings as ex officials to influence decision making process on matters concerning the students (Republic of Kenya, 2013).

From the foregoing it is evident that the participation of the student councils in decision making influences schools management. However, no empirical study has been done to ascertain that the participation student council in decision making influences the management of public boys' and girls' secondary schools. This researcher therefore identified that gap in knowledge and embarked on a study to establish that the participation of student councils of in decision making influences management of public boys' and girls' boarding secondary schools.

\subsection{Theoretical Framework}

\section{Contingency Theory}

According to (Dubrin, 2007) the contingency theory emphasizes the importance of the leadership keeping situation under control. However, matching the situation with the leader may create problems, because the amount of control the leader exercises varies from time to time. For example, if a relationship-oriented leader finds a good leader-follower situation for exercising control, it is almost certain that the leader would attempt to make the situation less favorable. As a result, the set goals may not be accomplished by a leader who has made the situation less favorable Virkus (2009). That is in agreement with assertion that good relationship between the leader and followers is important for making it easy for the leader to have influence and exercise control over the situation for achievement of the set goals of the organization. According to Virkus 2009 the contingency theory also explains that the difference in the participation of the student council in the management of public boys' and girls' boarding secondary schools emanate from lack of motivation and poor task structures of the student council. In this regard there are decisions on tasks for the students have not been made and that affect task accomplishment. The contingency theory explains that lack of definite task structure generates into conflicts in both public boys' and girls' boarding secondary schools that affects the internal climate/ culture of the school cohesive and harmonious co-existence.

\subsection{Conceptual Framework}

The study adopted the conceptual framework as shown below.

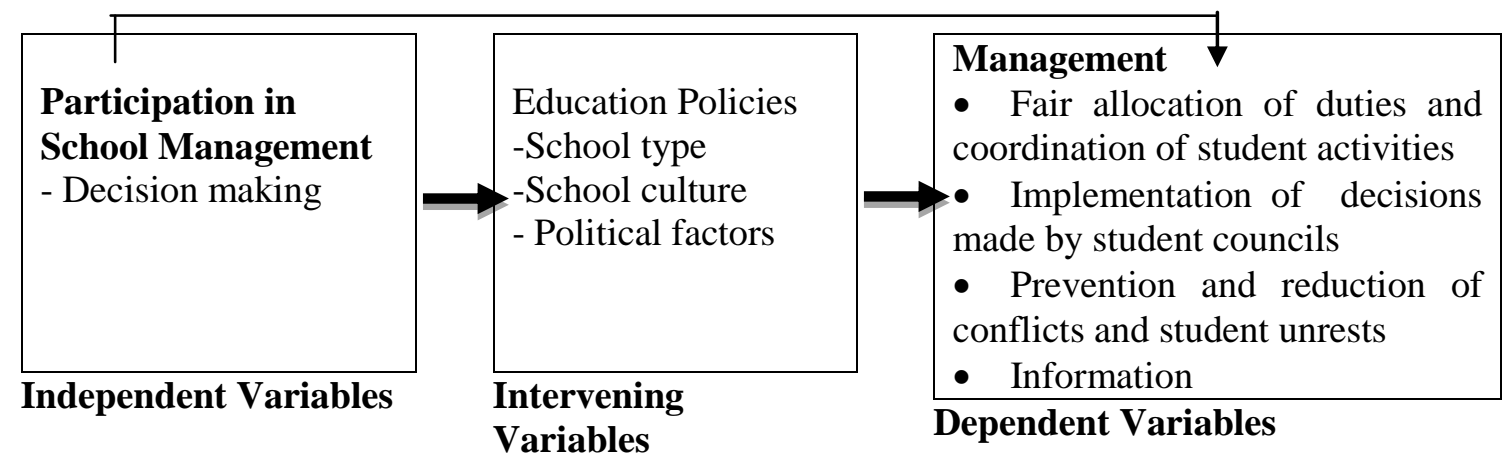

Figure 1: Participation of student councils in schools Management

\subsection{Methodology}

\subsection{Research Design}

This study adopted the descriptive survey research design. This design was appropriate in establishing, comparing and describing the relationships and the influence among the variables of the study (Kathuri \& Pals, 1993) and (Mugenda \& Mugenda, 2013). The design allowed descriptions and comparison of the current status of the participation of student councils in decision making, to influence management of public boys' and girls' in boarding secondary schools. 


\subsection{Location of Study}

The study was conducted in the Nyeri County which neighbors Laikipia, Meru, Kirinyaga, Muranga and Nyandarua counties (Institute of Economic Affairs (IEA), 2012). Nyeri County has six sub-counties which include Nyeri Town, Tetu, Mukurweini, Othaya, Mathira and Kieni with a total of 71 public boarding secondary schools. The county has a total of 28 boys' and 43 girls' public boarding secondary schools which the researcher needed to conduct a descriptive survey between boys and girls secondary schools (Republic of Kenya, 2013). Nyeri County had also been affected by persistent and devastating student unrests over the years mainly affecting boarding public secondary schools (MOE, 2008; 2015).

\subsection{Samples Size and Sampling Procedures}

Sampling is the process of selecting a representative group from the target population to participate in the study for generalization of results (Mugenda \& Mugenda (2013). A sample size of 384 respondents was drawn from a target population of 10,388target population in 71 boys' and girls' public boarding secondary schools in Nyeri Countyas recommended by Kathuri and Pals(1993). The study used systematic random sampling to select 72 Form 3 boys and 72 Form three girls from their entry in the class registers to participate in the study. Purposive sampling was used to select a total of 192 student council members comprising of 96 boys and 96 girls from 12 boys' and 12 girls' secondary schools. Purposive sampling was used to select one Form 3 class teacher and one deputy principal in each of the 24 schools. Purposive sampling was chosen because it allowed the researcher to reach the respondents that had the required information with respect to the objectives of study.

Table 1: Summary of the Sample Size

\begin{tabular}{lll}
\hline Variable & Target Population (N) & Sample Size (n) \\
\hline Form 3 boys & 3386 & 72 \\
Form 3 girls & 3948 & 72 \\
Student Council- Boys & 532 & 96 \\
Student Council- Girls & 533 & 96 \\
Class Teachers & 1917 & 24 \\
Deputy Principals & 71 & 24 \\
\hline Total & 10388 & 384 \\
\hline
\end{tabular}

\subsection{Instruments}

The research instruments that were used to collect data to establish the influence of student councils participation in the management of public boys and girls boarding secondary schools were questionnaires and interview schedule.

\subsection{Data Analysis}

Computations were made for the data using the Statistical Package for Social Sciences (SPSS) version 23. Descriptive statistics namely frequencies, percentages and measures of central tendency especially the mean and standard deviation were used to describe the characteristics of the collected data. To establish the influence of the participation of student council in decision making on schools management and also test the hypothesized influence, correlation and regression analysis were used. The regression equation to estimate effective management of public boarding secondary schools in Nyeri County was stated as:

$Y=\beta_{0}+\beta_{1} X_{1}+e$

Where $Y=$ School Management; $X_{1}=$ Decision making; $\beta_{0}=$ Constant

$\beta_{1}=$ Regression coefficient of decision making

$\mathrm{e}=$ Error term (identically, independent and normally distributed with a mean of zero (0) and variance of one (1). The independent sample t-test was chosen for this study because it was a comparison between means of variables in boys' and girls' schools. The results were presented using percentages distribution tables.

\subsection{Results and Discussions}

\subsection{The Response Rate}

The study had 358 respondents, who included the student council members, Form three students, and Form three class teachers and deputy principals of public boys' and girls' boarding secondary schools. Results of the response rate are shown in Table 2 
Table 2: Response Rate

\begin{tabular}{|l|l|l|l|}
\hline Respondent & Sample Size & Response & Response Rate \\
\hline Form 3 Students & 144 & 126 & 87.5 \\
\hline Student Council & 192 & 186 & 96.9 \\
\hline Class Teachers & 24 & 22 & 91.7 \\
\hline D/Principals & 24 & 24 & 100.0 \\
\hline Total & 384 & 358 & 93.2 \\
\hline
\end{tabular}

The results shown in Table 2 indicate that data was successfully collected from 358 respondents from the 6 subcounties in Nyeri County which contributed to $93.2 \%$ response rate. The results indicated that deputy principals had the highest response rate of $100 \%$ which may have been contributed by the fact that the deputy principals are school administrators responsible of protecting the school image by responding to public expectations. They were followed by the student council members $96.7 \%$, then the class teachers $91.7 \%$ and last were Form three students with $87.5 \%$.

\subsection{School Management}

There was an item in the questionnaire on the participation of student council in the management of public boys' and girls' boarding secondary school. Different sets of questions anchored on a five point Likert-type scale ranging from $1=$ strongly disagree to $5=$ Strongly Agree were used to measure the participation of student councils. The findings are displayed in Table 3.

Table 3: Descriptive Statistics on School Management

\begin{tabular}{|l|l|l|l|l|l|l|}
\hline Student council Participation in management & \multicolumn{3}{l}{ BOYS } & \multicolumn{2}{l|}{ GIRLS } \\
\cline { 2 - 7 } & $\mathrm{N}$ & Mean & SD & $\mathrm{N}$ & Mean & SD \\
\hline $\begin{array}{l}\text { S C has participated in the management of students } \\
\text { activities }\end{array}$ & 176 & 2.05 & 1.255 & 180 & 2.00 & 1.088 \\
\hline $\begin{array}{l}\text { Student councils have enhanced fairness in } \\
\text { allocation of duties }\end{array}$ & 178 & 2.04 & 1.266 & 180 & 2.63 & 1.694 \\
\hline Student councils participate in decision making & 178 & 2.33 & 1.300 & 180 & 2.77 & 1.554 \\
\hline $\begin{array}{l}\text { Student councils have helped the school } \\
\text { management to make good decisions }\end{array}$ & 178 & 2.13 & 1.241 & 180 & 2.27 & 1.222 \\
\hline $\begin{array}{l}\text { Student councils has helped to resolve student } \\
\text { conflicts }\end{array}$ & 178 & 2.01 & 1.110 & 180 & 2.28 & 1.320 \\
\hline $\begin{array}{l}\text { The student councils have helped to reduce classes, } \\
\text { ethnic and houses conflict }\end{array}$ & 178 & 2.02 & 1.125 & 180 & 2.29 & 1.339 \\
\hline $\begin{array}{l}\text { Creation of student councils has helped to reduce } \\
\text { student unrests }\end{array}$ & 178 & 2.13 & 1.223 & 180 & 2.10 & 1.242 \\
\hline $\begin{array}{l}\text { Student councils communicate to the school } \\
\text { administration about students }\end{array}$ & 178 & 1.85 & 1.189 & 180 & 1.89 & 1.162 \\
\hline $\begin{array}{l}\text { The student council communicate to the students } \\
\text { about school administration }\end{array}$ & 178 & 2.20 & 1.404 & 178 & 2.39 & 1.455 \\
\hline Overall Mean score & & 2.09 & 1.235 & & 2.29 & 1.342 \\
\hline
\end{tabular}

The results in Table 3indicate that the respondents, on average had a low rating on aspects of participation of student councils in school management with an overall mean score of 2.09 and 2.29 (2=disagree) for boys' and girls' school respectively. This implies that student councils do not participate adequately in management in public boarding secondary schools. The student councils had 1.455 rating in communication with the school administration where students had 1.89 mean score for boys' and 1.85 girls' schools respectively. Similarly, student councils participation in decision making had moderate mean score for girls' school with a mean of 2.77.

\subsection{Participation in Decision Making}

The study also sought to establish the effectiveness of student council participation in decision making to enhance the management of public boys' and girls' boarding secondary school. 
The respondents were asked to indicate the extent to which participation of student councils in decision making to enhance the management of boys' and girls' public boarding secondary schools. To measure participation in decision making process, ten items were used. Pertinent results are as shown in Table 4.

Table 4: Participation of Student Councils in Decision Making

\begin{tabular}{|l|l|l|l|l|l|l|}
\hline \multicolumn{2}{|l|}{} & \multicolumn{2}{l|}{ Boys } & \multicolumn{2}{l|}{ Girls } \\
\hline Participation in decision making process & $\mathrm{N}$ & Mean & SD & $\mathrm{N}$ & Mean & SD \\
\hline SC involved in school decision making & 178 & 3.55 & 1.50 & 180 & 3.46 & 1.38 \\
\hline Student councils meet regularly & 178 & 3.91 & 1.34 & 180 & 4.34 & 1.04 \\
\hline Student council member attend BOM meeting & 178 & 3.29 & 1.79 & 180 & 3.04 & 1.73 \\
\hline Discuss alternative solutions to issues & 178 & 3.78 & 1.20 & 180 & 4.10 & 1.03 \\
\hline Consult the school leadership on the solution & 178 & 3.89 & 1.19 & 178 & 4.07 & 1.20 \\
\hline Arrive at consensus on solution to a problem & 178 & 3.69 & 1.21 & 180 & 3.68 & 1.26 \\
\hline Communicate the decision to the students & 178 & 4.08 & 1.22 & 180 & 3.99 & 1.41 \\
\hline SC test the solution to the problem & 178 & 3.46 & 1.26 & 180 & 3.66 & 1.28 \\
\hline Implement the decision on the problem & 178 & 3.58 & 1.23 & 180 & 3.57 & 1.27 \\
\hline Student council give feedback to students & 178 & 3.54 & 1.41 & 180 & 3.94 & 1.26 \\
\hline Mean Score & & 3.68 & 1.33 & & 3.82 & 1.29 \\
\hline
\end{tabular}

The results in Table 4 reveal that mean scores for the ten statements used to measure participation in decision making process in boys' and girls' school was 3.68 and 3.82 respectively. This shows that respondents agreed (3.68 $\approx 4$ and $3.82 \approx 4$ ) that student councils were involved in decision making process by school administration. Notably, the respondents' in both boys' and girls' public boarding schools did not respond attendance of student council member board of management meetings (mean=3.29, $\mathrm{SD}=1.79$ and mean=3.04, $\mathrm{SD}=1.73$ ). In girls' schools, the respondents' agreed that student' councils meet regularly to discuss issues affecting students with highest mean score of 4.34 and $\mathrm{SD}=1.04$. By meeting regularly, the student council addressed all matters affecting students resulting to improvement of students' welfare. In boys' schools, the respondents' indicated that the student councils communicate decision made to the students with mean score of 4.08 and $\mathrm{SD}=1.22$.

\subsection{Test for Equality of Means for Decision Making}

The study sought to establish whether there was a statistically significant mean difference between participation of student council in decision making between boys' and girls' public boarding secondary schools. The results are displayed in Table 5.

Table 5: A t- Test on Participation in Decision Making

\begin{tabular}{|l|l|l|l|l|l|l|l|l|}
\hline Variable & $\begin{array}{l}\text { School } \\
\text { Type }\end{array}$ & $\mathbf{N}$ & Mean & SD & SE & $\begin{array}{l}\text { Mean } \\
\text { Diff }\end{array}$ & t-value & $\begin{array}{l}\text { P- } \\
\text { value }\end{array}$ \\
\hline $\begin{array}{l}\text { Decision- } \\
\text { Making }\end{array}$ & Boy & 178 & 3.68 & 0.96 & 0.07 & 0.14 & 1.15 & 0.25 \\
\cline { 2 - 8 } & Girl & 180 & 3.82 & 0.82 & 0.06 & & & \\
\hline
\end{tabular}

Table 5shows a t- test results of participation of student council in decision making in school management in public boys' and girls' boarding secondary schools which were $\mathrm{t}=1.15$; P-value $=0.25>0.05$ at $5 \%$ significance level. The results indicated that the participation of student council in decision making in both boys' and girls' public boarding secondary schools was the same. Meaning that, there is no statistically significant difference between the participation of student councils in decision making on the management of public boys' and girls' boarding secondary schools.

\subsection{Regression Analyses and Hypothesis Testingon Decision Making}

To establish the influence of participation of student councils in decision making on school management, the study sought to test the null hypothesis that stated that there is no statistically significant influence of participation of student councils in decision making on management of public boys' and girls' boarding secondary schools. The results obtained are summarized in the Table 6. 
Table6: Regression Results for Participation in Decision Making

(a) The Goodness - of- Fit

\begin{tabular}{|l|l|l|l|l|}
\hline Model & $\mathrm{R}$ & $\mathrm{R}$ Square & Adjusted R Square & Std. Error of the Estimate \\
\hline BOYS & $.573^{\mathrm{b}}$ & .329 & .325 & .75599 \\
\hline GIRLS & $.810^{\mathrm{b}}$ & .657 & .655 & .54793 \\
\hline COMBINED & 0.67 & 0.449 & 0.447 & 0.69181 \\
\hline
\end{tabular}

(b)

The Overall Significance of the Model

\begin{tabular}{|l|l|l|l|l|l|l|}
\hline Model & & $\begin{array}{l}\text { Sum of } \\
\text { Squares }\end{array}$ & df & Mean Square & F & Sig. \\
\hline \multirow{3}{*}{ BOYS } & Regression & 49.238 & 1 & 49.238 & 86.153 & $.000^{\mathrm{c}}$ \\
\cline { 2 - 8 } & Residual & 100.587 & 176 & .572 & & \\
\cline { 2 - 8 } & Total & 149.825 & 177 & & & \\
\hline \multirow{3}{*}{ GIRLS } & Regression & 102.207 & 1 & 102.207 & 340.430 & $.000^{\mathrm{c}}$ \\
\cline { 2 - 8 } & Residual & 53.441 & 178 & .300 & & \\
\cline { 2 - 8 } & Total & 155.648 & 179 & & & \\
\hline \multirow{2}{*}{ COMBINED } & Regression & 138.854 & 1 & 138.854 & 290.124 & $.000^{\mathrm{c}}$ \\
\cline { 2 - 8 } & Residual & 170.382 & 356 & 0.479 & & \\
\cline { 2 - 8 } & Total & 309.236 & 357 & & & \\
\end{tabular}

(c)

The Individual Significance

\begin{tabular}{|c|c|c|c|c|c|c|}
\hline \multirow[t]{2}{*}{ Model } & & \multicolumn{2}{|c|}{$\begin{array}{l}\text { Unstandardized } \\
\text { Coefficients }\end{array}$} & \multirow{2}{*}{$\begin{array}{l}\text { Standardized } \\
\text { Coefficients } \\
\text { Beta }\end{array}$} & \multirow[t]{2}{*}{$\mathrm{t}$} & \multirow[t]{2}{*}{ Sig. } \\
\hline & & $\mathrm{B}$ & $\begin{array}{l}\text { Std. } \\
\text { Error }\end{array}$ & & & \\
\hline \multirow[t]{2}{*}{ BOYS } & (Constant) & .805 & .149 & & 5.395 & .000 \\
\hline & Decision- Making & .552 & .059 & .573 & 9.282 & .000 \\
\hline \multirow[t]{2}{*}{ GIRLS } & (Constant) & .259 & .118 & & 2.204 & .029 \\
\hline & Decision- Making & .918 & .050 & .810 & 18.451 & .000 \\
\hline \multirow{2}{*}{$\begin{array}{l}\text { COMBINE } \\
\text { D }\end{array}$} & (Constant) & 0.604 & 0.1 & & 6.038 & .000 \\
\hline & Decision-Making & 0.699 & 0.041 & 0.67 & 17.033 & .000 \\
\hline
\end{tabular}

a. Dependent Variable: School Management

b. Predictor: (Constant), Decision Making

Simple regression mean scores of the management of public boys' and girls' boarding secondary schools against participation of the student councils in decision making yielded $\mathrm{R}^{2}=0.329$ for boys' and $\mathrm{R}^{2}=0.657$ for girls' as shown in Table 18. That implies that participation of student councils in decision making explained $32.9 \%$ and $65.7 \%$ for boys' and girls' respectively as variation in scores on the management of public boys' and girls' boarding schools.

The study revealed a statistically significant influence of the participation of student councils in decision making in enhancing management of public boys' and girls' boarding secondary schools whose Regression Coefficient was $(0.552 ; \mathrm{t}=9.282 ; \mathrm{P}$-value $=0.000<0.05)$ for boys' secondary schools and $(0.918 ; \mathrm{t}=18.451 ; \mathrm{P}$-value $=$ $0.000<0.05)$ for girls'. This implied that for a unit increase in participation of student councils in decision making,there was increase by a factor of 0.552 and 0.918 in effectiveness of management of public boys' and girls' in boarding secondary schools respectively.

The study therefore established that participation of student councils in decision making influences the management of public boys' and girls' boarding secondary schools. It was further established that the influence of the student council in decision making was slightly higher in girls' schools than in the public boys' boarding secondary schools in enhancing management. F-test was also used to establish the overall robustness and significance of the simple regression model for public boys and girls boarding secondary school for comparison purpose. The simple regression equation was statistically significant at 5\% level. For boys' in public boarding schools $\mathrm{F}=86.153$ and $\mathrm{P}$ - value $=0.000$ while the girls' in public boarding secondary school $\mathrm{F}=340.430$ and $\mathrm{P}$ value $=0.000$. 
The hypothesis that there is no statistically significant influence of the participation of student councils in decision making on the management of public boys' and girls' boarding secondary school was not supported by the study. The regression equations to estimate the influence of student councils on the management of public boys' and girls' boarding secondary schools in Nyeri County were stated as follows:

Boys: $Y=0.805+0.552 X_{1}$, Where $Y$ represent school management, $X_{I}$ represent decision making, 0.805 is a constant while 0.552 is the expected increase in management of public boys' boarding secondary schools in response to a unit increase in the participation of student councils in decision making. The regression coefficient constant of 0,805 for the boys' schools indicate the value of school management while the participation of the student council in decision making is at zero a unit increase in participation of student council in boys boarding secondary school in decision making would lead to a 0.552 increase in the management of public boys boarding secondary schools. On the basis of these findings, the study concluded that participation of student councils in decision making had statistically significant influence to the prediction of management of public boys' boarding secondary schools.

Girls: $Y=0.259+0.918 X_{1}$,

Where $Y$ represent effective management; $X_{l}$ represent decision making, 0.259 is a constant while 0.552 represent an estimate of the expected increase in the management of public girls boarding secondary schools in response to a unit increase in participation of student council in decision making. The regression coefficient constant of 0.259 for the girls' schools indicate the value of the school management while the participation of student councils in decision making is at zero the unit increase in participation of student councils in decision making would lead to a 0.918 increase in the effectiveness of management of public girls' boarding schools. On the basis of these findings the study concluded that participation of student councils in decision making had a statistically significant influence to the prediction of management of public girls' boarding secondary schools.

Regression of the aggregate mean scores of the management of public boarding secondary schools against participation of student councils in decision making yielded $\mathrm{R}^{2}$ of 0.449 as shown in Table 6 . This implied that participation of student councils in decision making explained $44.9 \%$ of the variation in scores for the management of public boarding secondary schools. The t-test statistic was used to determine individual significance of the influence. The study revealed a statistically significant influence between participation of student councils in decision making and the management of public boarding secondary schools (regression coefficient=0.699; $\mathrm{t}=17.033 ; \mathrm{P}$-value $=0.000<0.05$ ). This implied that a unit increase in participation of student councils in decision making, resulted in an increase in management of public boys' and girls' boarding secondary schools by a factor of 0.699 . Therefore, participation of student councils in decision making enhanced management of public boys' and girls' boarding secondary schools.

F-test was used to assess overall robustness and significance of the simple regression model. It was found that the regression equation was statistically significant at 5\% significance level $(\mathrm{F}=290.124$, $\mathrm{P}$-value=0.000). The hypothesis that there is no statistical significant influence of participation of student councils in decision making on the management of public boys' and girls' boarding secondary schools is not supported by the current study. The regression equation to estimate the management of public boys' and girls' secondary schools in Nyeri County was stated as

$Y=0.604+0.699 X_{1}$

Where $Y=$ School Management; $X_{l}=$ Decision making;

$0.604=$ constant

The 0.699 is an estimate of the expected increase in management of public boys' and girls' boarding secondary schools in response to a unit increase in participation of student councils in decision making. The regression coefficient of 0.604 under constant indicates the value of management when participation of student councils in decision making is at zero while a unit increase in participation of student councils in decision making would lead to a 0.699 increase in management of public boys' and girl' boarding secondary schools. On the basis of these findings, the study concluded that the participation of student councils in decision making had statistically significant contribution to the prediction of management of public boys' and girls' boarding secondary schools.

This finding concurred with study conducted in Britain by Huddleston (2007) that established that students councils were involved in decision making processes in their school but excluded from participating in sensitive decision making processes such as those related to examinations, academic performance and appointment of teachers. 
The finding of this study are also consistent with research by Fletcher (2005) in USA on "meaningful involvement of schools" which concluded that the burden of school management had shifted from educators' shoulders to sharing the responsibility of school management with students through consultation and decision making. The study had also found school management making deliberate effort to move from a secretive or opaque organization to one that encourages open access to information and decision making, which creates a higher level of trust among stakeholders.

The results on participation of student council in decision making are supported by studies conducted by Duma (2011), in South Africa that established that educators regard to participation student council in school governance as critical to democratization of the education system. However researchers maintained that that the student council participation should be limited and prescribed. Therefore in South Africa participation of the student council in decision making processes in secondary schools are guided by teachers and then adopted by the school management as policy direction. It was also established through a study by Magadla (2007) that student councils were allowed to participate in decision making processes with regard to school rules, rewards, curriculum, learning, development and planning of their school.

However, the studies done by Jeruto and Kiprop (2011) in Central Rift Valley of Kenya on the extent of student participation in decision making differ with the finding of this study that argue that the participation of student councils in decision making is often confined to issues concerned with student welfare and not in core school management issues while as this study found that student council deals with real management issues like decision making, conflict resolution and communication. However Otieno (2010) established that schools where students are not involved in decision-making or consulted whenever important decisions are being made, result to conflict between the students and the administration where students may vent their frustrations and disagreements with the school management through violence.

\subsection{Correlation Analysis for Participation in Schools Management}

The general objective of the study was to determine the participation of student councils in the management of public boys' and girls' boarding secondary schools in Nyeri County. In order to assess the relationships among the independent variable and dependent variable a Pearson's Product Moment Correlation (r) analysis was conducted. Results of the analysis are presented in Table 7.

Table 7: Correlation Analysis for Variables of Study

\begin{tabular}{|c|c|c|c|}
\hline Variable of study & & $\begin{array}{l}\text { School } \\
\text { Management }\end{array}$ & $\begin{array}{l}\text { Decision } \\
\text { Making }\end{array}$ \\
\hline \multirow[t]{2}{*}{ School Management } & $\begin{array}{l}\text { Pearson Correlation } \\
\text { Sig. (2-tailed) }\end{array}$ & 1 & \\
\hline & $\mathrm{N}$ & 358 & \\
\hline \multirow[t]{2}{*}{ Decision Making } & $\begin{array}{l}\text { Pearson Correlation } \\
\text { Sig. (2-tailed) }\end{array}$ & $\begin{array}{l}.670 * * \\
\mathbf{0 . 0 0 0}\end{array}$ & 1 \\
\hline & $\mathrm{N}$ & 358 & 358 \\
\hline
\end{tabular}

\subsection{Conclusion and Recommendation}

\subsection{Conclusions}

Participation of student councils in decision making had statistically significant influence on the management of public boys' and girls' boarding secondary schools. The study concluded that a unit increase in participation of student councils in decision making resulted in an increase by a factor of 0.699 in the management of public boys' and girls' boarding secondary schools. Therefore, participation of student councils in decision making enhances management of public boys' and girls' boarding secondary schools.

\subsection{Recommendations}

Participation of student councils in decision making promotes inclusiveness in the management of public boys' and girls' secondary schools. 
However the study recommended that school management should explore ways of ensuring that the student council participates in meeting where decisions for management of the school are made and also hold open forum where students' issues are fully discussed and feedback given to the school administration.

\section{References}

Abuya B. A \&Muhia N. (2016). Fighting Fire with Fire is Unlikely to Stem Kenya Student Unrest. United Kingdom: African Population and Health Research Center.

Black, R., \& Walsh, L. (2009).Corporate Australia and schools: Forming business class alliances and networks. Seminar Series Paper 182, February. Melbourne: Centre for Strategic Education.

Duma, M.A.H. (2011).Silent Leadership: Educators' Perceptions of the Role of Student Leadership in the Governance of Rural Secondary School. Centre for Promoting Ideas, USA: International Journal of Business and Social Science Vol. 2 No. 4

Dubrin, A. J. (2007). Leadership: Research, findings, practice and skills. $5^{\text {th }}$ edition. Boston Houghton Mifflin Company.

Fletcher, A. (2005). Meaningful Student Involvement. Nairobi: Sound Out.

Gatabu F. (2011). Influence of Administrators' Schools, Nairobi County - Kenya. University of Nairobi, Med Thesis, Department of Education Administration and planning. Treatment of Prefects on Discipline.

Hoy, W. K. \&Miskel, C. G. (2013). Education, Administration, Theory, Research and Practice, New York: McGraw Hill In.

Huddleston, T. (2007).From Student Voice to Shared Responsibility: Effective Practice in Democratic School Governance in European Schools. London: Citizenship Foundation

Institute of Economic Affairs (2012).Nyeri County. Nairobi: Government Press.

Indimuli, K. (2012). Effective students' council a tool kit for student council leadership, Nairobi: Track academic solutions.

Jeruto, B. T. \&Kiprop, J.C., (2011).Extent of Student Participation in Decision Making in Secondary Schools in Kenya.International journal of Humanities and Social Science. Vol. 1 No. 21

Kathuri, J. N. \& Pals A. D., (1993). Introduction to Educational Research, Njoro: Egerton University.

Keogh F.A., Whyte J. (2005). Second level Student Councils in Ireland. A Study of Enablers, Barriers and Supporters. Dublin: New Oceans.

KESSHA, (2010).The Implementation of Student Councils in Secondary Schools. Nairobi: Quanta Innovates Ltd.

Leithwood, K. Louis, K. S., Anderson, S., \&Wahlstrom, K., (2004). How leadership influences student learning. New York: Wallace Foundation.

Lynn D. and Yamashita H., (2007).Involving Children and Young People in Decisions which affect their Lives. Hertfordshire: Children Trust Partnership

Magadla, M. (2007).The Role of the Learner in the School Governing Body: Perceptions and Experiences of Principals, Educators, Parents and Learners. Unpublished Med Thesis: University of Kwazulu- Natal.

Masese, R., (2015). Status of Recent Student Unrest in Secondary Schools. Paper presented at Education Stakeholders Forum. Nairobi: Kenya Institute of Curriculum Development.

Modaff, D.P., Butler, J.A., DeWine, S. (2008). Organizational Communication: Foundations, Challenges, and Misunderstandings (Third Edition). Glenview: Pearson Education, 59-62.

MOE, (2008).Report on School Unrest in Central Province. Nyeri: Ministry of Education.

MOE.(2010). Kenya Guidelines for Formation and Implementation of Secondary Schools Student Councils. Nairobi: Elimu Publisher.

MOE, (2015).Report on Stakeholders on Student Unrest in Secondary Schools by July, 2015. Nairobi: Ministry of Education.

MOE (2016).Ministry of Education Records. County Educational Office, Nyeri.

MOE (2016).Preliminary Audit Report on the Causes of Riots in Secondary Schools. Nairobi: Ministry of Education.

Muchui, D. (2016). Why student unrests are on the rise in the country as 60 schools go strike in Meru. Dairy Nation, June 13, 2016 pg. 27

Mugenda, M. O. \&Mugenda, G. A. (2013).Research Methods, Quantitative and Qualitative Approaches. Nairobi: Acts Press. 
Ndungu, E. W. \&Kwasira, J. (2015). Contemporary Roles of Elected Student Council on Management of Public Secondary Schools in Kenya: A Survey of Selected Secondary Schools in Nakuru East Sub-County. International Journal of Innovative Research and Development, Vol. 4 Page 227.www.ijird.com.

Otieno, J. (2010). Establishing Effective Student Councils in your School. Nairobi: Rinny Education \& Technical Publishing Services.

Ouma W. \&Muide J. (2016).List of 126 Secondary schools hit by student unrest as of July 2016.www.nation.co.ke

Republic of Kenya, (1999).Total Integrated Education and Training, Report on the Commission of Inquiry into the Education System of Kenya. Nairobi: Government Printer.

Republic of Kenya, (2013).Nyeri County Development Profile. Nairobi: Government Printer.

Republic of Kenya, (2015).Basic Education Regulations, 2015. Kenya Gazette supplement No. 37. Nairobi: Government Press.

Ruto-Korir, R. (2003). "Violence in Kenyan Secondary Schools: an Insight into the Adolescent's SocioEmotional Development". Njoro: Egerton Journal Vol. IV, No.2\&3, pp. 53-68.

Sithole, S. (1998).The Participation of students in Democratic school Governance; Unpublished Med Thesis: University of KwaZulu-Natal.

Stokes, H., \& Turnbull, M. (2008).Real Engagement with Real Issues: An evaluation of the RUMAD program. A Report for Education Foundation. Melbourne: Youth Reference Centre.

Tikoko B.J. \&Kiprop C. J. (2011).Extent of Student Participation in Decision Making in Secondary Schools in Kenya. International Journal of Humanities and Social Science, 1(21) 34

Tirop, C. (2012). Student Involvement in School Governance - A Kenyan Experience. The $7^{\text {th }}$ Africa Conference of Principals (16-37). Nairobi: Kessha Secretariat.

UNICEF (2010).Progress Report for UNICEF Education in Emergencies and Post- Crisis Transitional Program Nairobi: UNICEF, Kenya.

Virkus, S. (2009). Strengths of Contingency Approach. Tallinn University.

Wango, G. M., (2009). School Administration and Management: Quality Assurance and Standards in Schools. Nairobi: Jomo Kenyatta Foundation. 